\title{
固体鎖状高分子の誘電吸収の形について*
}

\author{
高柳素夫** 石田陽一** 山藤 馨** 伊藤秀男** 松尾正人**
}

\section{Shape of Dielectric Absorption Curves in Solid Linear High Polymers}

\author{
by \\ Motowo Takayanagi, Yōichi Ishida, Kaoru Yamafuji, \\ Hideo Itō and Masato Matsuo \\ (Department of Applied Chemistry, Kyushu University, Fukuoka)
}

Two sorts of dielectic absorption coming from the amorphous part are observed in each of the usual solid linear high polymers. The absorption of the high temperature (low frequency) side is called the $\alpha_{a}$-absorption and that of the low temperature (high frequency) side the $\beta_{a}$-absorption.

The shapes of the $\alpha_{a^{-}}$and $\beta_{a}$-absorptions are discussed both in experimental and theoretical ways with respect to the dependences of the width and the asymmetry of the absorption curves upon the degree of crystallinity and the chemical structure. Cole-Cole's parameter $\bar{\beta}$ and the parameter of the sech-law $\bar{\alpha}$ are adopted in this paper for representing the characteristic features of the shape of the dielectric absorption curve semi-quantitatively. The shape of the $\alpha_{a}$. absorption is discussed at much higher temperatures than $T_{g}$ and the shape of the $\beta_{a}$-absorption at much lower temperatures than $T_{g}$, because the shape of the absorption curve scarecely changes with temperature at these respective temperature ranges.

The observed results are as follows : $(\alpha .1)$ Cole-Cole's parameter $\bar{\beta}$ for the $\alpha_{a}$. absorption curve of the typical amorphous polymer takes the value of $0 \cdot 7 \sim 0 \cdot 8$, where $\bar{\beta}$ becomes a little smaller with the increase of the steric effect, at least for the polymers which have resemble chemical structures. The $\bar{\beta}$ of the polymer which seems to lie between the amorphous and the crystalline polymer (such as PVC and PAN) takes the value of $0.5 \sim 0.6$. The value of $\bar{\beta}$ decreases with the increase of the degree of crystallinity in the typical crystalline polymer and tends to the value of $0 \cdot 2 \sim 0 \cdot 3$. $(\alpha .2)$ The $\alpha_{a}$-absorption curve shows a little asymmetrical shape if it is plotted in logarithm of the frequency scale. The higher frequency side of the absorption curve is a little gentler than the lower freqnency side for the amorphous polymer. With the increase of the degree of crystallinity, the $\alpha_{a}$-absorption curve becomes symmetric and, finally, the lower frequency side becomes gentler. ( $\beta .1$ ) The $\bar{\beta}$ of the $\beta_{a}$-absorption curve takes the value of $0 \cdot 2 \sim$ 0.4 irrespectively with the degree of crystallinity and with the chemical structure. ( $\beta .2)$ The shape of the $\beta_{a}$-absorption is relatively symmetrical excepting the cases of aromatic polyesters.

The theoretical expressions of the shapes of the $\alpha_{a}$-and $\beta_{a}$-absorptions are derived. The calculation is made on the basis of the following mechanisms; that is, the $\alpha_{a}$-absorption is due to the segmental micro-Brownian motions of the main chains in the amorphous part and the $\beta_{a^{-}}$ absorption is due to the local motions of the main chains in the amorphous part such as the local distortions of the chains in the frozen state. The agreements between the theory and the observations are satisfactory.

(Received Jan. 29, 1962)

\section{1. 緒論}

固体鎖状高分子について誘電性あるいは粘弾性の測 定を行なうと, 一般に 2 種類あるいは 3 種類の吸収が 見いだされることはすでに明らかにされており，これ らは高温側か $5 \alpha$ 吸収, $\beta$ 吸収, $\gamma$ 吸収と呼ばれてい

* 原稿受付 昭和 37 年 1 月 29 日

***州大学工学部
る.しかしこれらの呼称は分子機構と関連なしに，単 に出現の順序に従ったものであり，混乱を招くことが 多い，そこで著者は無定形領域分子鎖のミクロブラ ウン運動に基づく吸収を $\alpha_{a}(a$ は無定形領域を意味 す）と呼び，これを基準にとり，以下低温側に $\beta, \gamma$ な ぞと呼ぶことを提案している。これは $\alpha_{a}$ 吸収が無定 形高分子については最もよく理解されており，かつ結 
晶性高分子についても，その判定が比較的容易である ことによる。ポリェチレン，ポリプロピレンなどの結 晶性のきわめて高い高分子においては $\alpha_{a} よ り$ 高温側 に結晶領域に由来する吸収が見いだされ，これを著者 は $\alpha_{c}$ と呼んでいる。 また $\alpha_{a}$ 吸収より低温側に無定形 領域の分子鎖のきわめて局所的動きに基づく吸収が存 在し，これを著者らは $\beta_{a}$ 吸収と呼んでいる。したが ってたとえばポリェチレンの場合には，一般の呼称に よる $\alpha$ が $\alpha_{c}$ に，また $\beta$ が $\alpha_{a}$ に，そうして $\gamma$ が $\beta_{a}$ に対 応することになる。ナイロン，ポリウレタンなどの水 素結合を有する高分子では 3 種類の吸収が粘弾性なら びに誘電性の測定において見いだされているが，その うち中間に位置する吸収は吸湿水分に由来するもので あり，乾燥試料では $\alpha_{a}$ と $\beta_{a}$ に対応する吸収のみが存 在する. その他, ビニル重合体や, ポリェステルなど 多くの高分子においては， $\alpha_{a}$ と $\beta_{a}$ に対応する吸収の みが見いだされている例がほとんどのようである。本 論文においては誘電性の面から，これらの $\alpha_{a}$ 吸収な らびに $\beta_{a}$ 吸収のみを議論の対象にすることにする。

誘電性の測定においては, 最近測定器の進歩により, 吸収曲線の全貌を単一の装置により容易に測定するこ とが可能となった。これは粘弾性の測定に比べて, 誘 電性の測定のすぐれている点である。吸収曲線を規定 するおもな因子として，その幅と対称性があげられる が, 従来の研究は主としてその幅のみ在対象としてい る。そこで, 本論文においては, $\alpha_{a}$ 吸収および $\beta_{a}$ 吸 収について, 誘電吸収曲線の形が, 化学構造および微 細構造にいかに依存するかを，その幅のみならず対称 性の面からも実験的ならびに理論的に検討することを 試みた。

\section{2. 測定結果の整理法について}

粘弾的ならびに誘電的緩和の測定結果を理論と比較 する場合に最も一般性がある方法と信じられているも のは緩和時間スペクトルによる方法である。誘電緩和 の場合には, 遅延時間スペクトルと呼ぶべさものを慣 習上, 緩和時間スペクトルと呼んでいるのであるが, それは次式で定義される。

$$
\frac{\varepsilon^{*}(i \omega)-\varepsilon_{\infty}}{\varepsilon_{0}-\varepsilon_{\infty}}=\int_{-\infty}^{\infty} \frac{L_{\varepsilon}(\ln \tau)}{1+i \omega \tau} d(\ln \tau)
$$

ここでは $\omega$ は外電場の角周波数，ては緩和時間である。 (1)式は Stieltjes一Hilbert 逆変換を用いて

$$
L_{\varepsilon}(\ln \tau)=\frac{1}{\pi} \text { imaginary part of }\left[\frac{\varepsilon^{*}\left(e^{-i \pi} \tau^{-1}\right)-\varepsilon_{\infty}}{\varepsilon_{0}-\varepsilon_{\infty}}\right]
$$

と書くこともできる。測定結果から緩和時間スペクト ルを実際に求めるのは原理的には可能であるが，実際 には測定点の密度と精度の限界上, 信頼できるのはせ いぜい一次近似の緩和時間スペクトル $L_{\varepsilon}(\ln \tau)$ にすぎ
ない。一次近似の緩和時間スペクトルは複素誘電率の 実部 $\varepsilon^{\prime}$ の測定曲線から次のように微分によって求め られる。

$$
L_{\varepsilon}^{[1]}(\ln \tau)=\left\{-\omega \frac{d}{d \omega}\left[\frac{\varepsilon^{\prime}(\omega)-\varepsilon_{\infty}}{\varepsilon_{0}-\varepsilon_{\infty}}\right]\right\}_{\omega=\tau^{-1}}
$$

誘電吸収の場合のように比較的狭い幅をもつ吸収の 場合には(2)式と（3)式とははなはだしく異なった曲 線を与えることがありうるので(Fig. 8 参照)，一次近 似の緩和時間スペクトル自体はなんら特別の物理的意 味を持たないこともありうる。したがってわざわざ精 度の悪い微分操作を施してまで, 測定データから (3) 式の形の緩和時間スペクトルを求めても意味がないよ うに思われる。むしろ測定される $\varepsilon^{\prime} v s . \log f$ 曲線ある いは $\varepsilon^{\prime \prime} v s . \log f$ 曲線を理論と比較するほうが簡単であ り，当を得た方法であるように思われる。

著者らが議論の対象とする吸収曲線の測定データの 整理を行なう場合, 測定曲線の特徴を数量的に表わす パラメーターを採用することが望ましい．しかし，上 に述べた理由により実験的に求めた近似的な緩和時間 スペクトルのこう配が誘電吸収の場合には物理的にあ まり意味を持たないものである以上, 粘弾性の場合に 用いられるような緩和時間スペクトルのこう配に匹敵 する量は現在のところ見あたらない（粘弾性の場合 には吸収曲線の幅は充分に広いので，緩和時間スペク トルの平均のこう配は，たとえ一次近似で求められた ものにしろ，実際の緩和時間スペクトルのこう配にか なり近いものと思われる).

したがって著者らは便宜的な方法にすぎず，物理的 に意味を持ったものとは思われないのであるが，これ まで誘電的測定データの整理に用いられてきた実験的 近似式を測定データの整理の際には借用することにし， 理論と測定結果の比較の際には吸収曲線自体を用いる ことにしよう.

これまで主として用いられてきた実験的近似式は 3 種類あり，それぞれ次の式で示される。

$$
\begin{aligned}
& \operatorname{sech} \text { 則 } * * * \frac{\varepsilon *(i \omega)-\varepsilon_{\infty}}{\varepsilon_{0}-\varepsilon_{\infty}}=\frac{1}{1+\left(i \omega \tau_{m}\right)^{\bar{\alpha}}} \\
& \text { Cole-Cole 則 }{ }^{4}: \frac{\varepsilon^{*}(i \omega)-\varepsilon_{\infty}}{\varepsilon_{0}-\varepsilon_{\infty}}=\frac{1}{1+i\left(\omega \tau_{m}\right)^{\bar{\beta}}} \\
& \text { 5) }: \frac{\varepsilon^{*}(i \omega)-\varepsilon_{\infty}}{\varepsilon_{o}-\varepsilon_{\infty}}=\frac{1}{\left(1+i \omega \tau_{m}\right)^{\bar{\gamma}}}
\end{aligned}
$$

これらはそれぞれ次の緩和時間スペクトルを持つ。

$$
L_{\varsigma}(\ln \tau)=\frac{\bar{\alpha}}{\pi} \frac{\cos (\bar{\alpha} \pi / 2) \cosh \left\{\bar{\alpha} \ln \left(\tau / \tau_{m}\right)\right\}}{\sinh ^{2}\left\{\bar{\alpha} \ln \left(\tau / \tau_{m}\right)\right\}+\cos ^{2}(\bar{\alpha} \pi / 2)}
$$

\footnotetext{
* ポリシクロヘキシルメタフクレートなどにおいては $\beta_{8} a$ 吸収より さらに低温に $\gamma_{a}$ 吸収が存在することが知られているし，またポ リテトラフルオロエチレンに扎いては 3 種類以上の吸収が見いだ されているがこのような例は現在のところではまだ数少ないよ らである

** Sech 則はその虚部つみが正しい意味を持つにすぎないが，ここ では形式の統一上この表式を選んだ
} 


$$
\begin{aligned}
& L_{c}(\ln \tau)=\frac{1}{2 \pi} \frac{\sin \bar{\beta} \pi}{\cosh \left\{\bar{\beta} \ln \left(\tau / \tau_{m}\right)\right\}+\cos \bar{\beta} \pi} \\
& L_{l}(\ln \tau)=\frac{1}{\pi} \frac{\tau^{\bar{\gamma}} \sin \left(\bar{\gamma} \tan ^{-1} \tau_{m} / \tau\right)}{\left(\tau^{2}+\tau_{m}^{2}\right)^{\bar{\gamma} / 2}}
\end{aligned}
$$

ここで $\tau_{m}=1 / \omega_{m}$ は吸収曲線 $\varepsilon^{\prime \prime}(\omega) /\left(\varepsilon_{0}-\varepsilon_{\infty}\right)$ が極大 になる角周波数に対応する綏和時間である。

(4)式および(5)式で表わされる吸収曲線を $\ln (\omega /$ $\left.\omega_{m}\right)$ に対してプロットすると対称な形を与えるが，測 定される誘電吸収の形は一般の場合は必ずしも完全に 対称ではない（6)式の吸収曲線を $\ln \left(\omega / \omega_{m}\right)$ に対し てプロットすると高周波側がややゆるやかな非対称性 を与えるが．これも無定形高分子の $\alpha_{a}$ 吸収の場合を 除いては測定データとは，必ずしも一致しない．

しかしながら誘電吸収の非対称度はあまり大きくな い場合がかなり多いので, 近似的には Cole-Cole 則の $\bar{\beta}$ および $\ln L_{c}(\ln \tau) v s . \ln \tau$ 曲線の平均のこう配 $\bar{g}$ を 決定できる．この場合 $\bar{g}$ は緩和時間分布曲線のゆるや かさをきわめてあらい近似で表わすパラメーターとな $\eta$, 粘弾性緩和の場合の遅延時間スペクトルのこう配 と比較すれば, 誘電緩和と粘弹性緩和の相違を認識す る上にある程度役だつ量であるように思われる。さら にまた，著者らは吸収曲線の極大点の低周波側と高周 波側で別々にsech 則を適用し, パラメーター $\bar{\alpha}_{I}$ (低 周波側)ならびに $\bar{\alpha}_{H}$ (高周波側)を定め， $\bar{\alpha}_{L}$ と $\bar{\alpha}_{H}$ の 大小関係により吸収曲線の非対称度を数量的に表わす ことにした．以上述べてきたような方法により吸収曲 線の特徵を記述することはできるが，しかし必ずしも 満足できる方法でないことは注意しておく必要があろ j.

\section{3. 測定結果に基つくく吸収曲線の特徵}

$\alpha_{a}$ 吸収も $\beta_{a}$ 吸収もその形は温度によって变化する。 $\alpha_{a}$ 吸収の形はガラス転移域では温度の上昇とともに その幅が狭くなる傾向を示し， $\beta_{a}$ 吸収についても同 様なことがいえる。しかしながら $\alpha_{a}$ 吸収の形は $T_{g}$ 上 り充分高温域で，一方 $\beta_{a}$ 吸収の形は $T_{g}$ より充分低温 域で温度によりほとんど変化しないことが測定結果を 調べてみるとわかる。したがって $\alpha_{a}$ 吸収もしくは $\beta_{a}$ 吸収の形がほとんど変化しない温度域において種々の 物質における誘電吸収の形を比較することにより，温 度に無関係に吸収の形の結晶化度依存性もしくは化学 構造依存性についての知識を整理することができる。 以下に示す測定結果および議諭は，この意味で $\alpha_{a}$ 吸 収については $T_{g}$ より充分高温域の $\beta_{a}$ 吸収については $T_{g}$ 上り充分低温域のものに限ることにする。なお， Table 1 に数種の高分子の $\bar{\beta}, \bar{g}, \bar{\alpha}_{L}$ ならびに $\bar{\alpha}_{H}$ の 值が示される。

\section{(I) $\alpha_{a}$ 吸収}

各温度における $\varepsilon^{\prime \prime}$ vs. $\log f$ 曲線を $\varepsilon^{\prime \prime}{ }_{\text {max }}$ の值で規
格化したものにつき重㸚合わせを行なうと，たとえば Fig. 1 に示されるように重㸚合わせが成立する。しか しながら，Ferry の重祇合わせは無定形高分子におい てさえ無条件に成立するわけでなく，他の種類の吸収 の寄与がない場合にのみ成立するのである，たとえば Fig. 2 に polymethyl acrylate の $\alpha_{a}$ 吸収の測定結 果が示されているが， $\beta_{a}$ 吸收の笴与がない低周波側 では重效合わせが可能であり， $\beta_{a}$ 吸収の寄与が含ま れている高周波側で重福わせが成立しない， $\beta_{a}$ 吸 収のほうが $\alpha_{a}$ 吸収より shift factor が小さく，した がって温度の上昇ととも $\alpha_{a}$ 吸収は $\beta_{a}$ 吸収に接近す ることになり， $\alpha_{a}$ 吸収に対する $\beta_{a}$ 吸収の寄与は增大 する傾向にあるので, Fig. 2 の結果は当然期待される

Table 1 Values of $\bar{\beta}, \bar{g}, \bar{\alpha}_{L}$ and $\bar{\alpha}_{H}$

\begin{tabular}{c}
\hline \\
\hline
\end{tabular}

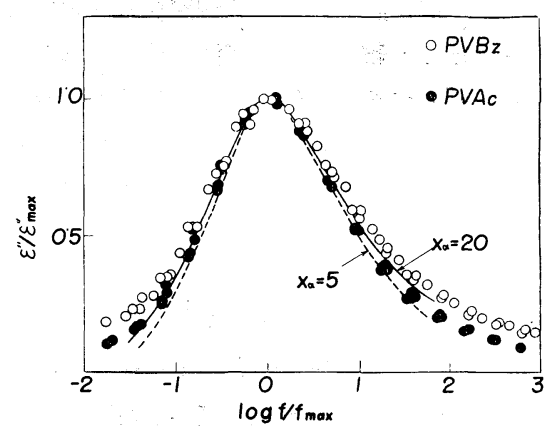

Fig. 1 The superposition of the normalized $\alpha_{a}$-absorption curves in PVAc and PVBz and the comparison between the observation and the theoretical curves calculated by Eq. (7). The dotted line corresponds to the case of $x_{\alpha}=5$ in Eq. (7) and the solid line corresponds to the case of $x_{\alpha}=20$ in Eq. (7) 
ところである。このような事実は広い周波数域にわた る測定を実施することにより，はじめて明らかとなる が, 非晶性, 結晶性を問わず見いだされる実験事実で ある、したがってやむをえず狭い周波数範囲の測定結 果に基づき広い周波数範囲にわたる master curve を 作製する際には，共存する他の吸収からの寄与を充分 に注意しなければならない.

以下に測定された $\alpha_{a}$ 吸収の形の特徴をあげてみる と,

（1）非晶性高分子においては Table 1 にあげた 以外のものについても $\beta$ の值は $0.7 \sim 0.8$ の間に大体 存在し, 同一系列の高分子について比較すると， bulky な側鎖を有するもののほうが小さい闪の值を示 す.すなわち $\varepsilon^{\prime \prime} v s . \log f$ 曲線の幅が広い(Fig. 1参照). また $\varepsilon^{\prime \prime} v s . \log f$ 曲線の形は高周波側の傾斜のほうが 低周波側の傾斜よりゆるやかである。いかえると， sech 則のパラメーターの值は高周波側で定めた值 $\left(\bar{\alpha}_{H}\right)$ のほうが低周波側で定めた值 $\left(\bar{\alpha}_{L}\right)$ より小さい.

(2) Polyvinyl chloride (PVC) や polyacrylonitrile (PAN) などの 典型的非晶性高分子と典型的 $\bar{\beta}$ 結晶性高分子の中間の性格を示す高分子においては $\bar{\beta}$ の值は $0.5 \sim 0.6$ であり, また $\varepsilon^{\prime \prime} v s . \log f$ 曲線の形 は比較的対称な形を示す (Fig. 3 参照).

(3) 結晶性高分子の急冷により得られた無定形試 料は $\bar{\beta}$ の値は $0.6 \sim 0.7$ であるが，結晶化度が増大す るとともに急激に減少して, 充分に結晶化した試料で は $\bar{\beta}$ の值は $0.2 \sim 0.3$ 程度になる。また $\varepsilon^{\prime \prime} v s . f$ 曲線 の形は無定形試料において非晶性高分子の場合と同様 に高周波側がややゆるやかな傾斜を示すが，中程度の 結晶化度を示す試料では PVC, PAN などの場合と同 様に対称がよくなり，結晶化度が充分高くなると逆に

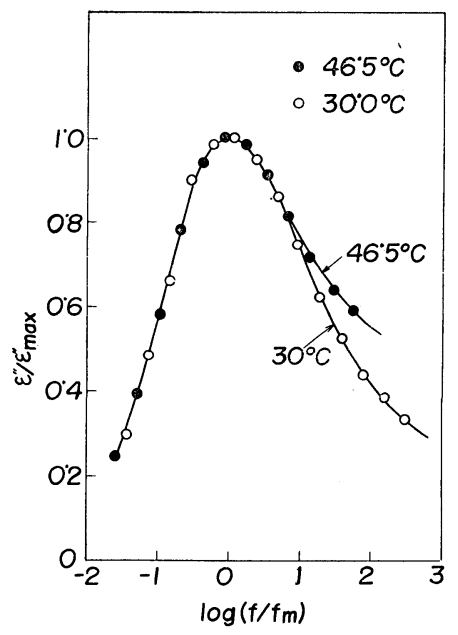

Fig. 2 The superposition of the normalized $\alpha_{a}$-absorption curves in PMA
低周波側の傾斜がゆるくなる (Fig. 3 の PET (結晶化 度 0.5$)$ 参照）。すなわち結晶化度の増加とともに $\bar{\alpha}_{L}$ $>\bar{\alpha}_{H} \rightarrow \bar{\alpha}_{L} \approx \bar{\alpha}_{H} \rightarrow \bar{\alpha}_{L}<\bar{\alpha}_{H}$ の経過をたどる. Polyethylene terephthalate(PET), polyparaethylene oxybenzoate (PEOB) の場合について, 結晶化度に対 する $\bar{\alpha}_{L}$ および $\bar{\alpha}_{H}$ の変化を図示すると Fig. 4 のよ うになる。結晶化度の初期の变化が $\bar{\alpha}_{L}$ および $\bar{\alpha}_{H}$ に顕 著な影響を与え, それ以後の変化はこれに比べてゆる やかである。また $\bar{\alpha}_{L}$ と $\bar{\alpha}_{H}$ では $\bar{\alpha}_{L}$ のほうが結晶化 度の初期の変化に鋭敏である。

$\bar{\beta}$ の值が非晶性高分子においては化学構造の变化と ともに,たかだか $0.7 〜 0.8$ の間程度の変化しか示さ ないのに対し，結晶性高分子においては結晶化度の変 化とともに0.2〜0.7 の間の変化を示す.また， $\bar{\alpha}_{L}$ と $\bar{\alpha}_{H}$ の大小関係も主として結晶化度に依存する。した がって $\alpha_{a}$ 吸収曲線の幅および対称性はいくぶん化学 構造によっても左右されるが，主として結晶化度に依 存するという実験的結論が得られる。

(II) $\beta_{a}$ 吸収

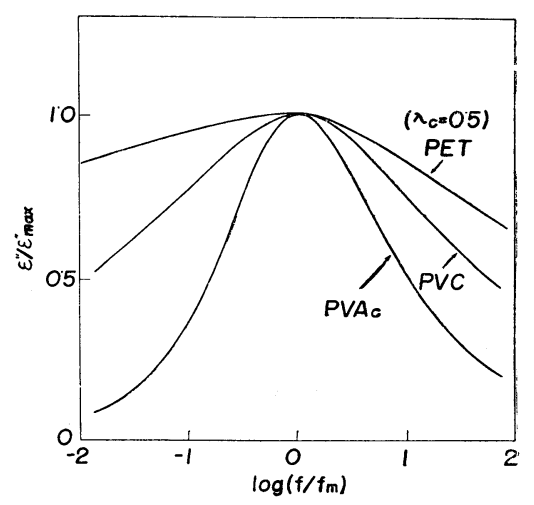

Fig. 3 The comparison among the normalized $\alpha_{a}$-absorption curves

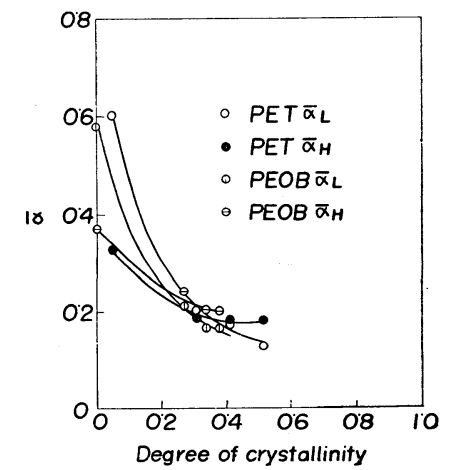

Fig. 4 The Dependences of $\bar{\alpha}_{L}$ and $\bar{\alpha}_{H}$ upon the degree of crystallinity in PET and PEOB 
$\beta_{a}$ 吸収の $T_{g}$ より充分に低い温度域における $\varepsilon^{\prime \prime} v s$. $\log f$ 曲線を $\varepsilon^{\prime \prime}$ max で規格化したものにつき重ね合わ せを行なうと，たとえば Fig. 5 に示すように，大体 において重ね合わせが可能である。このことは非晶性 高分子のみならず, 結晶性高分子においても一般に成 立する。これは $T_{g} よ り$ 充分低温では $\alpha_{a}$ 吸収は充分低 周波側に移動し, しかも小さくなっているので $\beta_{a}$ 吸 収への寄与がほとんどないことにもよるのである.

$\beta_{a}$ 吸収の $\bar{\beta}$ の值は $0.2 \sim 0.4$ の間にあり, 非晶性高 分子において同一系列の高分子を比較する場合， $\alpha_{a}$ 吸収に比べて,さらに化学構造依存性は小さいように 思われる(Fig. 5 参照)。 また結晶性高分子における結 晶化度依存性も，たとえば Fig. 6 に示される程度で あり， $\alpha_{a}$ 吸収の場合よりはるかに小さい，芳香族ポ リエステルの $\beta_{a}$ 吸収の $\varepsilon^{\prime \prime} v s . \log f$ 曲線は非対称であ

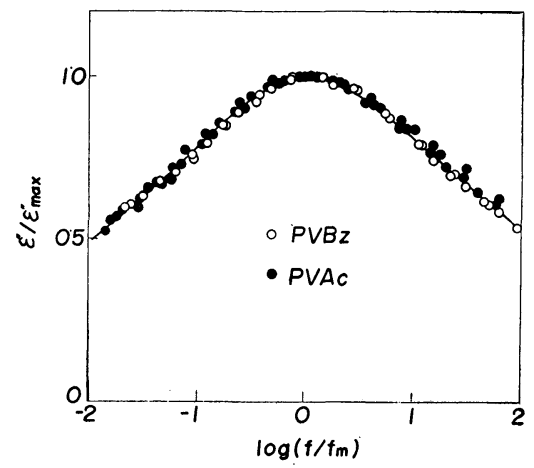

Fig. 5 The superposition of the normalized $\beta_{a}$-absorption curves in PVAc and PVBz in glassy state. The comparison between the observation and the theoretical curve calculated on the assumption of $A^{\beta}=A^{\prime \beta}$ in Eq. (8)

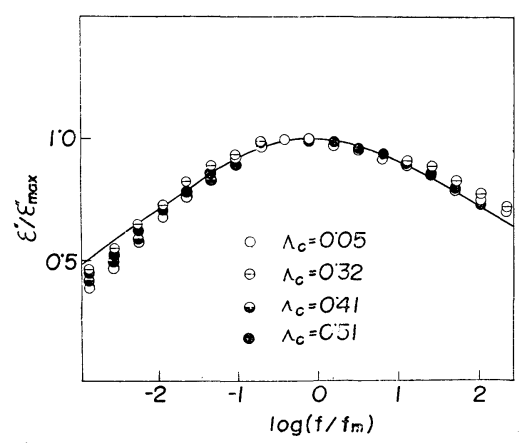

Fig. 6 The dependence of the $\beta_{a}$-absorption curve upon the degree of crystallinity in PET. The comparison between the observed data and the theoretical curve calculated under the assumption of $A^{\prime \beta}$ $=2 A^{\beta}$ in Eq. (8)

るが(Fig. 6 参照)，一般には結晶性，非晶性によらず 比較的良好な対称性老示す。

\section{4. 理論と測定結果の比較}

固体極性高分子の $\alpha_{a}$ 掞よび $\beta_{a}$ 吸収に対して簡単な 計算老行なった結果，次の式が得られた。

$$
\begin{aligned}
& {\left[\frac{\varepsilon^{*}(i \omega)-\varepsilon_{\infty}}{\varepsilon_{0}-\varepsilon_{\infty}}\right]_{\alpha}=\int \frac{L_{\alpha}\left(\ln \tau_{\alpha}\right) d\left(\ln \tau_{\alpha}\right)}{\sqrt{\left(1+i \omega \tau_{\alpha} x_{\alpha}\right)\left(1+i \omega \tau_{\alpha} x_{\alpha}^{-1}\right)}}(7)} \\
& {\left[\frac{\varepsilon^{*}(i \omega)-\varepsilon_{\infty}}{\varepsilon_{0}-\varepsilon_{\infty}}\right]_{\beta}} \\
& =\int \frac{\left(1+i \omega \tau_{\beta} x_{\beta}\right) L_{\beta}\left(\ln \tau_{\beta}\right) d\left(\ln \tau_{\beta}\right)}{\sqrt{\left(1+i \omega \tau_{\beta} x_{\beta}\right)\left(1+i \omega \tau_{\beta} x_{\beta}\right)\left(1+i \omega \tau_{\beta} x_{\beta}\right)\left(1+i \omega \tau^{(5)} x\right)}}
\end{aligned}
$$

ただし

$$
\left.\begin{array}{rl}
\tau_{\alpha} \cong \zeta^{\alpha} & {\left[\left(4 \mathrm{~A}^{\alpha}+\mathrm{B}^{\alpha}+\mathrm{C}^{\alpha}\right)\left(\mathrm{B}^{\alpha}+\mathrm{C}^{\alpha}\right)\right]^{-1 / 4}} \\
\times & {\left[\left(\left\{4 \mathrm{~A}^{\alpha}+\mathrm{B}^{\alpha}+\mathrm{C}^{\alpha}\right)\left(\mathrm{B}^{\alpha}+\mathrm{C}^{\alpha}\right)\right\}^{1 / 2}+4 \mathrm{D}^{\alpha}\right]^{-1 / 2}} \\
x_{\alpha} \cong & {\left[\left\{\left(4 \mathrm{~A}^{\alpha}+\mathrm{B}^{\alpha}+\mathrm{C}^{\alpha}\right)\left(\mathrm{B}^{\alpha}+\mathrm{C}^{\alpha}\right)\right\}^{1 / 2}+4 \mathrm{D}^{\alpha}\right]^{1 / 2}} \\
& /\left[\left(4 \mathrm{~A}^{\alpha}+\mathrm{B}^{\alpha}+\mathrm{C}^{\alpha}\right)\left(\mathrm{B}^{\alpha}+\mathrm{C}^{\alpha}\right)\right]^{1 / 4}
\end{array}\right\}
$$

および

$$
\begin{aligned}
& \tau_{\beta} \cong \zeta^{\beta}\left[\left(2 \mathrm{~A}^{\beta}+2 \mathrm{~A}^{\prime \beta}+\mathrm{B}^{\beta}+\mathrm{C}^{\beta}\right)\left(\mathrm{B}^{\beta}+\mathrm{C}^{\beta}\right)\right]^{-1 / 2} \\
& \underset{x_{\beta}}{x}\left[\left(2 \mathrm{~A}^{\beta}+2 \mathrm{~A}^{\prime} \beta+\mathrm{B}^{\beta}+\mathrm{C}^{\beta}\right)\left(\mathrm{B}^{\beta}+\mathrm{C}^{\beta}\right)\right]^{1 / 2}
\end{aligned}
$$

$\stackrel{(2)}{x_{\beta} \cong[}$

(3)

$x_{\beta} \cong[$

$\stackrel{(4)}{x_{\beta} \cong[}$

$\stackrel{(5)}{x_{\beta} \cong[}$

である。

これらの式は $\alpha_{a}$ 吸収は主鎮セグメントのミクロブ ラウン運動に基づき, $\beta_{a}$ 吸収は $T_{g}$ 以下で主鎖セグメ ントのミクロブラウン運動が凍結している状態におけ る主鎖セグメント内の局部的なねじれ運動などに基づ くものとして計算されている。計算は主鎖の構成単位 程度の大きさのものを運動単位に選び，それに対する 平均的な運動方程式を解くという方法で行なわれた。

簡単のために，運動単位あたりの合成双極子を単に双 極子と呼ぶことにすれば，らは双極子の回転摩擦係数 であり，A 鎖内の，Bは鎖間の隣接双極子から受け る弾性力の定数である、C は双極子のつり合いの方向 への弾性復元力の定数であり, Dはェントロピー弾性 力の定数である。大体の值は

$$
\left.\begin{array}{l}
4 \mathrm{~A}^{\alpha}+\mathrm{B}^{\alpha}+\mathrm{C}^{\alpha} \leq k T_{g}, 4 \mathrm{D}^{\alpha} \sim k T \\
2 \mathrm{~A}^{\beta} \sim 5 \mathrm{eV}, \quad \mathrm{B}^{\beta}+\mathrm{C}^{\beta} \sim k T_{g}
\end{array}\right\}
$$

の程度である。この際， $\alpha_{a}$ 吸収に対するこれらの定 数の值はセグメント内にわたって平均された量である が， $\beta_{a}$ 吸収に対するこれらの值はそうではない。し 
たがって，たとえばある双極子の主鎖に沿った両側の 要素が異なったものであれば，それぞれが双極子に及 ぼす弹性的な復元力の定数は異なってくるはずである。 (10)式内では，このことを考慮に入れて， $\mathrm{A}^{\beta}$ と $\mathrm{A}^{\prime \beta}$ の二つの量が現われている，もちろん，双極子の主鎖 に沿った両側の要素が等しければ $\mathrm{A}^{\beta}=\mathrm{A}^{\prime} \beta$ である. $L(\ln \tau)$ は双極子が受ける回転摩擦係数の值の分布に 基づく吸収曲線の広がりを表わす量であって，無定形 領域中の双極子密度の不均一性に由来するものである。

(7)式抢よび $\mathrm{A}^{\beta}=\mathrm{A}^{\prime \beta}$ としたときの (8)式中には， 通常現われる Debye factor $(1+i \omega \tau)^{-1}$ の代わりに $\left[(1+i \omega \tau x)\left(1+i \omega \tau x^{-1}\right)\right]^{-1 / 2}$ が現われている。鎖でつ ながっているために生ずる復元力 $\left(\mathrm{A}^{\alpha}, \mathrm{D}^{\alpha}\right.$ および $\mathrm{A}^{\beta}$, $\left.\mathrm{A}^{\prime \beta}\right)$ が零に近づいた極限に执いては $x \rightarrow 1$ となって上 の因子は Debye fectorに近づく.すなわち鎖でつな がっている效果と，隣接鎖間の相互作用を上の式では 考虑した形になっている。また，結晶化の影響は無定 形領域中の密度の不均一性に由来する双極子の回転摩 擦係数の值の分布 $(L(\ln \tau))$ という形で含まれている.

\section{(I) 非晶性高分子の $\alpha_{a}$ 吸収の形}

$\alpha_{a}$ 吸収は主鎖セグメントのミクロブラウン運動に 基づくものと考えられているが， $T_{g} よ り$ 充分高温で は主鎖セグメントのミクロブラウン運動は活発なので セグメント内にわたって平均された各双極子が受ける 回転摩擦係数もほぼ等しい值をもつと考えてよいであ ろう。したがって近似的に

$$
L_{\alpha}(\ln \tau) \cong \delta\left(\tau_{\alpha}-\tau_{\alpha}{ }^{0}\right) ; T \gg T_{g}
$$

と仮定することができよう。また， $x_{\alpha}$ は物質により異 なるが，(9)，(11)式より大体 $1<x_{\alpha}<30$ 程度の範囲 にあることがわかる。一般に $x_{\alpha}$ の值の変化に伴う $(7)$ 式の吸収曲線の变化は比較的わずかであって，これは 非晶性高分子における $\alpha_{a}$ 吸収の非対称性がさほど大 きくないことに対応する。 Fig. 1 には $x_{\alpha}=5$ の曲線 を PVAc, $x_{\alpha}=20$ の曲線を $\mathrm{PVBz}$ の測定曲線とそれ ぞれ比較してある。非晶性高分子の $\alpha_{a}$ 吸収の実測さ れた幅の程度は Kirkwoodらの計算によって得られた ものと大体一致するが，かれらの結果では高周波側が ややゆるやかな非対称をもつことは得られていない.

Fig. 7 は Kirkwood らの結果であるが, 測定とはむ しろ逆の非対称性が得られている。

なお Fig. 8 には(12)式を代大した際に(7)式から 得られる緩和時間スペクトル $L_{\varepsilon}(\ln \tau)$ と，その一次近 似の $L_{\varepsilon}^{[1]}(\ln \tau)$ とが比較されている. 白点はPVAの実 測結果より求めた $L_{\varepsilon}(\ln \tau)$ であって理論と実测とよく 一致するにもかかわらず, $L_{\varepsilon}(\ln \tau)$ と $L_{\varepsilon}(\ln \tau)$ の間に は大きな相違がみられる。

\section{(II) 結晶性高分子の $\alpha_{a}$ 吸収の形}

最初に無定形試料について考える。結晶性高分子の

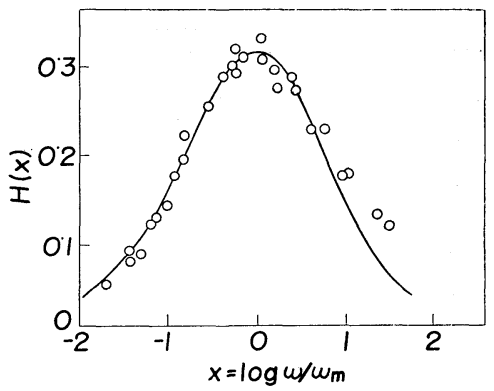

Fig. 7 Comparison between the $\alpha_{a}$-absorption curve of PVAc and the theoretical curve by Hammarle-Kirkwood (J. Chem. Phys., 23, 1743 (1955))

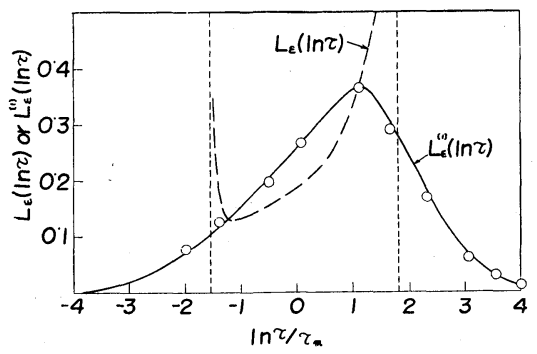

Fig. 8 Comparison between the theoretical curve and the observation for the 1st approximated relaxation time spectrum $L(\ln \tau)$. The circles are calculated from the observed data of PVAc by Eq. (3) and the solid curve is the theoretical curve of $L_{\varepsilon}^{[1]}(\ln \tau)$ calculated by Eqs. (3), (7) and (12). The dotted curve is the theoretical relaxation time spectrum $L_{\varepsilon}$ ( $\ln \tau$ ) calculated by Eqs. (2), (7) and (12)

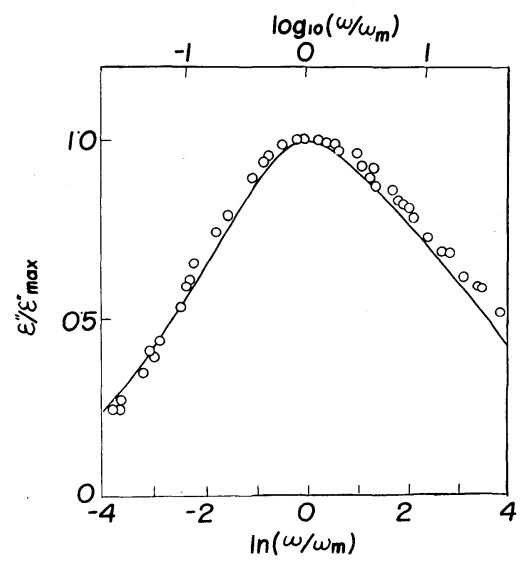

Fig. 9 Comparison between the normalized $\alpha_{a}$-absorption curve in the amorphous sample of PET and the theoretical curve calculaled by Eq. (7) 
無定形試料は溶融状態より急冷することにより調製さ れる。したがってX線的には無定形とはいっても，純 粋な非晶性のそれと異なり, 結晶組織に近い部分があ ちこちに散在しているものと推定され，(12)式の近似 はもはや成立しない．現在の理論では $L_{\alpha}\left(\ln \tau_{\alpha}\right)$ の分 子論的表式は得られていないが，無定形試料において は双極子密度の局部的ばらつきは平均値のまわりに対 称な分布をしているものと推定されるので，そのよう に仮定するならば， $L_{\alpha}(\ln \tau)$ は $\ln \left(\tau / \tau_{m}\right)$ に対して対 称な分布を示すものとして導かれる。誘電吸収曲線が 対称な場合にはColeの曲線によく乗るので, $L_{\alpha}\left(\ln \tau_{\alpha}\right)$ をColeの分布関数 ( 5$)^{\prime}$ 式で近似的に置き替えること にする. Fig. 9 にはPET の無定形試料に対して $\bar{\beta}=$ $0 \cdot 65, x_{\alpha}=20$ の理論曲線が比較されている。 $x_{\alpha}$ の值は $\mathrm{PVB} z$ もしくは PEI に対して決めた值を用い， $\vec{\beta}$ の值 は低周波側実測值と大体一致するように選ばれている。

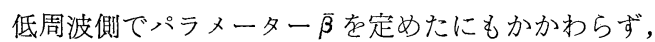
( 7 )式より計算された理論曲線は図に示されるように 高周波側においても実測值と良い一致を示している。

結晶化度を充分に上げると逆に低周波側の傾斜がゆ るやかになる傾向を示すが，これは結晶化度の増大に 伴い，無定形部分の双極子の一部が拘束を受けるため に，回転摩擦係数の值の大きい部分が占める割合が増 大し， $L(\ln \tau)$ が低周波側でややゆるやかな分布をも つようになることを考慮すれば，定性的には理解でき る。しかしながら $L(\ln \tau)$ の分子論的表式は得られて いないので，それ以上の説明は将来の課題として残さ れる。

\section{(III) 非晶性高分子の $\beta_{a}$ 吸収の形}

非晶性高分子の $\beta_{a}$ 吸収に対する $\bar{\beta}$ の值は $0.2 \sim 0.4$ であり，対称性は芳香族ポリエステルの場合を除けば かなり良いが，詳細にみると高周波側がややゆるやか な非対称性を示す。 $x_{(5)} x_{\beta}$ の值は $\mathrm{A}^{\prime} \beta=\mathrm{A}^{\beta}$ の場合には(10) 式より $x_{\beta} \cong \sqrt{300}, x_{\beta}=1 / x_{\beta}$ となる. Fig. 5 には PVAc と $\mathrm{PVBz}$ に対する $(8)$ 式の理論曲線が実測值と比較さ れている。 $L_{\beta}\left(\ln \tau_{\beta}\right)$ としては前と同様にCole の分布 関数を選び, $\beta=0.37$ の值はやはり低周波側が実測曲 線と一致するように定められた。
PEIの場合には構造式からわかるように主鎖中に含 まれるフェニレン基の立体障害のため $\mathrm{A}^{\beta} \neq \mathrm{A}^{\prime} \beta$ となり， (8)式の理論曲線は高周波の傾斜のほうがゆるやかな 非対称性を示し，実験結果をよく説明する．Fig. 6 に は $\mathrm{A}^{\prime} \beta=2 \mathrm{~A}^{\beta}$ と選んだ場合の理論曲線が示されている (PET の実測值と比較されているが，これは $\beta_{a}$ 吸収 の形に関しては結晶化度の影響が小さく，かつPEI と PET の $\beta$ 吸収曲線の形の間に大した差異がみとめら れないことによる).

\section{(IV) 結晶性高分子の $\beta_{a}$ 吸収の形}

$\beta_{a}$ 吸収の形は結晶化度が増大しても， $\alpha_{a}$ 吸収にみ られるような著しい相違は観測されない(Fig. 6 参照). これは $\beta_{a}$ 吸収が，局所的な緩和に基づくことによる のであろう。しかしながら， $\beta_{a}$ 吸収が充分に幅広い ため，形の変化の度合が見掛上では，それほど顕著に 現われないというここも考慮されねばならぬように思 われる。

本研究の進行にあたり，数々の有益な御助言をいた だいた九州大学工学部電子工学教室の入江教授ならび に，装置の製作にあたり，種々便宜をはかっていただ いた生産機械教室の上野教授に深く感謝する。また， 種々の試料を提供していただいたかたがたに対し厚く 感謝する。

\section{参考 文 献}

1）高楖素夫，高分子，10，289（1961)

2) K.H. Illers, Makromol. Chem., 38, 168 (1960)

3) R.M. Fuoss and J.G. Kirkwood,J. Am. Chem. Soc., 63, 385 (1941)

4) K.S. Cole and R.H. Cole, J. Chem. Phys., 9, 341 (1941)

5) D.W. Davidson and R.H. Cole, J. Chem. Phys., 18, 1417 (1950): 19, 1484 (1951)

6) K. Yamafuji and Y. Ishida, Kolloid Z., 175, 27 (1961)

7) Y. Ishida, Kolloid Z., 174, 124 (1961)

8) Y. Ishida and K. Yamafuji, Kolloid Z., 177, 97 (1961)

9) Y. Ishida, Kolloid Z., 168, 29 (1960)

10) Y. Ishida, O. Amano and M. Takayanagi., 172, 129 (1960)

11) 山藤㢣, 物性論研究, 3 集, 9 巻, 111 (1961)

12) K. Yamafuji and Y. Ishida, Kolloid Z., (in press)

13) W.G. Hammarle and J.G. Kirkwood, J. Chem. Phys., 23, 1743 (1955) 